\title{
IMPLEMENTASI STANDAR NASIONAL PENDIDIKAN DALAM MENINGKATKAN DAYA SAING MADRASAH IBTIDAIYAH NEGERI 1 GORONTALO
}

\author{
Halik S. Maranting ${ }^{1}$, Muh. Arif ${ }^{2}$, Abdurrahman R. Mala ${ }^{3}$ \\ ${ }^{123}$ Pascasarjana IAIN Sultan Amai Gorontalo \\ Email: marantinghalik97@gmail.com
}

\begin{abstract}
ABSTRAK
Artikel ini bertujuan untuk menganalisis implementasi standar Nasional pendidikan dalam meningkatkan daya saing Madrasah, mengingat standar tersebut menjadi isu penting diterapkan bagi pengelolaan pendidikan. Metode penelitian yang digunakan dalam penelitian ini adalah deskriptif (pemaparan). Data primer diperoleh dari pengamatan dan wawancara langsung. Data sekunder adalah data yang diperoleh dari sumber tertulis yang terkait dengan penelitian ini. Hasil penelitian menunjukkan bahwa implementasi standar nasional pendidikan dalam meningkatkan daya saing Madrasah Ibtidaiyah Negeri 1 Kota Gorontalo sudah terealisasi dengan baik mengacu pada delapan standar pendidikan nasional sehingga dapat meningkatkan daya saing Madrasah dan memperoleh nilai akreditasi A.
\end{abstract}

Kata Kunci: Standar Nasional Pendidikan, Daya Saing

\begin{abstract}
This article aims to analyze the implementation of national education standards in increasing the competitiveness of Madrasahs, considering that these standards are an important issue for the management of education. The research method used in this research is descriptive (exposure). Primary data were obtained from direct observation and interviews. Secondary data is data obtained from written sources related to this research. The results showed that the implementation of national education standards in improving the competitiveness of Madrasah Ibtidaiyah Negeri 1 Gorontalo City has been well realized by referring to the eight national education standards so that it can increase the competitiveness of Madrasahs and obtain an A accreditation score.
\end{abstract}

Keywords: National Education Standards, Competitiveness

\section{PENDAHULUAN}

Pada hakikatnya pendidikan dalam konteks pembangunan nasional mempunyai fungsi: (1) pemersatu bangsa, (2) penyamaan kesempatan, dan (3) pengembangan potensi diri. Pendidikan diharapkan dapat memperkuat keutuhan 
bangsa dan Negara Kesatuan Republik Indonesia (NKRI), memberi kesempatan yang sama bagi setiap warga negara untuk berpartisipasi dalam pembangunan, dan memungkinkan setiap warga negara untuk mengembangkan potensi yang dimilikinya secara optimal, bermutu, relevan dengan kebutuhan masyarakat, dan berdaya saing dalam kehidupan global.

Visi pendidikan nasional adalah mewujudkan sistem pendidikan sebagai pranata sosial yang kuat dan berwibawa untuk memberdayakan semua warga negara Indonesia agar berkembang menjadi manusia yang berkualitas sehingga mampu dan proaktif menjawab tantangan zaman yang selalu berubah. Misi pendidikan nasional adalah: (1) mengupayakan perluasan dan pemerataan kesempatan memperoleh pendidikan yang bermutu bagi seluruh rakyat Indonesia; (2) meningkatkan mutu pendidikan yang memiliki daya saing di tingkat nasional, regional, dan internasional; (3) meningkatkan relevansi pendidikan dan kebutuhan masyarakat dan tantangan global; (4) membantu dan memfasilitasi pengembangan potensi anak bangsa secara utuh sejak usia dini sampai akhir hayat dalam rangka mewujudkan masyarakat belajar; (5) meningkatkan kesiapan masukan dan kualitas proses pendidikan untuk mengoptimalkan pembentukan kepribadian yang bermoral; (6) meningkatkan keprofesionalan dan akuntabilitas lembaga pendidikan sebagai pusat pembudayaan ilmu pengetahuan, keterampilan, pengalaman, sikap, dan nilai berdasarkan standar yang bersifat nasional dan global; dan (7) mendorong peran serta masyarakat dalam penyelenggaraan pendidikan berdasarkan prinsip otonomi dalam konteks Negara Kesatuan Republik Indonesia. Standar Nasional Pendidikan berfungsi sebagai dasar dalam perencanaan, pelaksanaan, dan pengawasan pendidikan dalam rangka mewujudkan pendidikan nasional yang bermutu, untuk penjaminan dan pengendalian mutu pendidikan sesuai dengan Standar Nasional Pendidikan dilakukan evaluasi, akreditasi, dan sertifikasi.

Pemerintah mengategorikan madrasah yang telah memenuhi atau hampir memenuhi Standar Nasional Pendidikan ke dalam kategori mandiri, dan Berbagai upaya ditempuh agar alokasi sumberdaya Pemerintah Pusat dan Pemerintah Daerah diprioritaskan untuk membantu madrasah yang belum masuk ke dalam kategori standar dan dari kategori standar untuk bisa meningkatkan diri menuju kategori mandiri. bagi madrasah yang telah masuk kategori mandiri, Pemerintah mendorongnya untuk secara bertahap mencapai taraf internasional. Dengan terpenuhinya komponen Standar Nasional Pendidikan, maka Madrasah Ibtidaiyah diharapkan mampu menyesuaikan diri sehingga dapat memiliki keunggulan yang kompetitif. Namun pada kenyataannya masih banyak Madrasah Ibtidaiyah yang belum memenuhi standar nasional pendidikan, bahkan ada yang belum terakreditasi. Dari hasil penjajagan awal di lapangan juga terlihat adanya beberapa komponen standar nasional pendidikan yang belum terlaksana dengan baik, 
sehingga peneliti merasakan pentingnya untuk mengadakan penelitian tentang Implementasi Standar Nasional Pendidikan dalam Meningkatkan Daya Saing Madrasah Ibtidaiyah Negeri 1 Kota Gorontalo yang difokuskan terhadap pelaksanaan delapan standar nasional pendidikan; (1) standar isi, (2) standar proses; (3) standar kompetensi lulusan; (4) standar pendidik dan tenaga kependidikan; (5) standar sarana dan prasarana; (6) standar pengelolaan; (7) standar pembiayaan; dan (8) standar penilaian pendidikan.

Madrasah hadir untuk membekali peserta didik dengan pengetahuan agama, pengetahuan umum, keterampilan, kesenian maupun pengembangan minat dan bakat peserta didik. Semua itu dalam rangka mempersiapkan peserta didik yang unggul dalam prestasi, cerdas, terampil dan berakhlakul karimah sebagai wujud persaingan, berbagai upaya dilakukan untuk merebut hati dan mendapat kepercayaan dari calon para peserta didiknya sebagai pelanggan (customers). kaitannya dengan persaingan dan kepercayaan, masyarakat berasumsi bahwa semakin bermutu suatu pendidikan maka semakin kuat daya saingnya dihadapan pelanggannya, bahkan jika ada lembaga pendidikan yang memiliki mutu yang baik, banyak program unggulan yang dilaksanakan yang bisa membentuk karakter anak didiknya menjadi orang yang hanif, dengan kesadaran diri melaksanakan ajaran Islam, serta kemandirian tertanam di jiwanya, maka lembaga seperti itu akan mendapatkan kepercayaan dari masyarakat. Lembaga pendidikan yang memiliki mutu baik serta mempu bersaing dengan yang lainnya, diantaranya Madrasah Ibtidaiyah Negeri 1 Kota Gorontalo, keunikan Madrasah ini yaitu memadukan antara kurikulum DIKNAS, KEMENAG. Madrasah Ibtidaiyah Negeri 1 Kota Gorontalo pada periode tahun 2017-2018 jumlah peserta didiknya 541 orang, periode tahun 2018-2019 jumlah peserta didiknya meningkat menjadi 778 orang, jumlah yang besar bagi madrasah negeri, hal itu yang perlu digali dan di ungkap oleh peneliti, bagaimana implementasi standar nasional pendidikan yang telah dijalankan sehingga lembaga tersebut memiliki kualitas unggul dan daya saing kuat dalam menghadapi persaingan dengan madrasah yang lain di daerah Provinsi Gorontalo.

\section{HAKIKAT DAN FUNGSI STANDAR NASIONAL PENDIDIKAN}

Ki Hajar Dewantara mengemukakan bahwa pendidikan yaitu usaha yang dilakukan dengan penuh keinsyafan yang ditunjukkan untuk keselamatan dan kebahagiaan manusia. Dan dalam hal ini Al-Syaibani menjelaskan bahwa pendidikan adalah mengubah tingkah laku individu dalam kehidupan pribadinya sebagai bagian dari kehidupan masyarakat dan kehidupan alam sekitarnya. ${ }^{1}$ Pendidikan adalah usaha sadar dan terencana untuk mewujudkan suasana belajar

${ }^{1}$ Alfi Syahril Fuadi Jaya, Ellywati, Implementasi Standar Nasional Pendidikan di Kabupaten Aceh Besar Suatu Persepsi dan Harapan Masyarakat. Pendidikan Ekonomi FKIP Universitas Syiah Kuala, Vol. 3, No.1, Banda Aceh: Universitas Abulyatama, 2019. h. 4-5. 
dan proses pembelajaran agar peserta didik secara aktif mengembangkan potensi dirinya untuk memiliki kekuatan spiritual keagamaan, pengendalian diri, kepribadian, kecerdasan, akhlak mulia, serta keterampilan yang diperlukan dirinya, masyarakat, bangsa dan negara (Pasal 1 Ayat 1), dan Pendidikan Nasional adalah pendidikan yang berdasarkan Pancasila dan Undang-Undang Dasar Negara Republik Indonesia Tahun 1945 yang berakar pada nilai-nilai agama, kebudayaan nasional Indonesia dan tanggap terhadap tuntutan perubahan zaman (Pasal 1 Ayat 2). Jadi Standar nasional pendidikan adalah kriteria minimal tentang sistem pendidikan di seluruh wilayah hukum Negara Kesatuan Republik Indonesia. $^{2}$

Berangkat dari definisi diatas dapat difahami bahwa sistem pendidikan indonesia diarahkan pada tercapainya cita pendidikan yang ideal dalam rangka mewujudkan peradaban bangsa Indonesia yang bermartabat. Standar Nasional Pendidikan adalah kriteria minimal tentang sistem pendidikan di seluruh wilayah hukum Negara Kesatuan Republik Indonesia (UU Nomor 20 Tahun 2003 tentang Sistem Pendidikan Nasional Pasal 1 ayat 17 dan PP Nomor 19 Tahun 2005 tentang Standar Nasional Pendidikan). Standar Nasional Pendidikan diharapkan mampu memberikan arah dan koridor pelaksanaan bagi penyelenggara pendidikan sehingga tujuan pendidikan nasional mampu diupayakan dengan dukungan seluruh jajaran pelaksana dan penyelenggara pendidikan. Standar Nasional Pendidikan dapat dianggap sebagai salah satu langkah kongkrit peningkatan mutu pendidikan dengan pemberdayaan sekolah agar mampu berperan sebagai subyek penyelenggara pendidikan dengan menyajikan pendidikan yang bermutu. Sekolah diberi kewenangan dan peran yang luas untuk merancang dan melaksanakan pendidikan sesuai dengan potensi dan kondisinya masing-masing dengan tetap mengacu pada standar minimal yang ditetapkan pemerintah melalui Standar Nasional Pendidikan (SNP). Sesuai dengan Peraturan Pemerintah Nomor 19 Tahun 2005 tentang Standar Nasional Pendidikan pasal 3 yang berbunyi "Standar Nasional Pendidikan berfungsi sebagai dasar dalam perencanaan, pelaksanaan, dan pengawasan pendidikan dalam rangka mewujudkan pendidikan nasional yang bermutu". Hal ini berarti bahwa Standar Nasional Pendidikan menjadi acuan dan menjadi persyaratan minimal yang harus dipenuhi oleh setiap penyelenggara pendidikan pada setiap tahap dan proses pendidikan. Dari fungsinya di atas dapat dipahami bahwa Standar Nasional Pendidikan adalah kriteria minimal tentang sistem pendidikan di seluruh wilayah hukum Negara Kesatuan Republik Indonesiayang berfungsi sebagai dasar dalam perencanaan, pelaksanaan, dan pengawasan pendidikan dalam rangka mewujudkan pendidikan nasional yang

${ }^{2}$ Peraturan Menteri Pendidikan Nasional Republik Indonesia No. 19 tahun 2005 tentang Standar Nasional Pendidikan. (Jakarta: Direktorat Pembinaan Sekolah Menengah Atas, 2019), h. 9. 
bermutu yang bertujuan menjamin mutu pendidikan nasional dalam rangka mencerdaskan kehidupan bangsa dan membentuk watak serta peradaban bangsa yang bermartabat.

\section{RUANG LINGKUP STANDAR NASIONAL PENDIDIKAN}

Lingkup Standar Nasional Pendidikan merupakan komponenkomponen utama yang merupakan suatu kesatuan yang tidak dapat dipisahkan. Menurut Peraturan Pemerintah Nomor 19 Tahun 2005 tentang Standar Nasional Pendidikan pasal 2 ayat 1 menyatakan bahwa "Lingkup Standar Nasional Pendidikan meliputi 1) Standar Isi; 2) Standar Proses; 3) Standar Kompetensi Lulusan; 4) Standar Pendidik dan Tenaga Kependidikan; 5) Standar Sarana dan Prasarana; 6) Standar Pengelolaan; 7) Standar Pembiayaan; dan 8) Standar Penilaian. Sebagai suatu sistem, delapan komponen standar nasional pendidikan di atas, membentuk sinergi dalam menciptakan sebuah integrasi, sehingga membangun hubungan fungsional yang menunjang terwujudnya tujuan pendidikan nasional. Hal ini berimplikasi bahwa setiap satuan pendidikan di seluruh Indonesia harus mencapai atau menerapkan ke delapan standar di atas sebagai standar pelayanan minimal di bidang pendidikan. Akan menjadi lebih baik lagi apabila satuan pendidikan bisa melampaui standar yang telah ditentukan. Berikut uraian dari masing-masing komponen Standar Nasional Pendidikan tersebut:

\section{Standar Isi}

Standar isi adalah ruang lingkup materi dan tingkat kompetensi yang dituangkan dalam kriteria tentang kompetensi tamatan, kompetensi bahan kajian, kompetensi mata pelajaran, dan silabus pembelajaran yang harus dipenuhi oleh peserta didik pada jenjang dan jenis pendidikan tertentu. (Permendiknas Nomor 22 Tahun 2006 Pasal 1 ayat (1). Hamalik dalam Abdul Rahmat, mengemukakan bahwa kurikulum adalah rencana tertulis tentang yang harus dimiliki berdasarkan standar nasional, materi yang perlu dipelajari dan pengalaman belajar yang harus dijalani untuk mencapai kemampuan peserta didik. ${ }^{3}$ Kurikulum adalah seperangkat mata pelajaran dan program pendidikan yang diberikan oleh suatu lembaga penyelenggara pendidikan yang berisi rancangan pelajaran yang akan diberikan kepada peserta didik dalam suatu periode jenjang pendidikan tertentu. Allah swt., berfirman dalam Al-Qur'an Surat Luqman ayat 14:

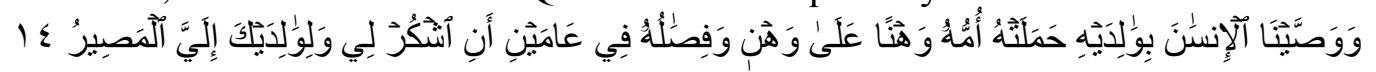
Terjemahnya:

Dan Kami perintahkan kepada manusia (berbuat baik) kepada dua orang ibu-bapaknya; ibunya telah mengandungnya dalam keadaan lemah yang bertambah-tambah, dan menyapihnya dalam dua tahun. Bersyukurlah

\footnotetext{
${ }^{3}$ Abdul Rahmat, Pengantar Pendidikan (Teori, Konsep dan Aplikasi), (Gorontalo: Ideas Publishing, 2014), h. 93.
} 
kepada-Ku dan kepada dua orang ibu bapakmu, hanya kepada-Kulah kembalimu. ${ }^{4}$

Ayat tersebut menjelaskan tentang materi pendidikan akhlak terhadap kedua orang tua yang telah mengandung, melahirkan, dan membesarkan dengan susah payah. Seorang peserta didik harus menghormati, menghargai, dan berbuat baik kepada orang tua (guru) bukan semata-mata karena guru berjasa dalam mentransfer ilmu pengetahuan dan menanamkan nilai, tetapi lebih dari itu guru pada hakikatnya adalah orang tua yang harus dihormati dan dimuliakan. Sikap menghormati merupakan salah satu cara manusia memanusiakan manusia lainnya, sebab menghormati orang lain tidaklah membuat diri hina, ataupun kehilangan kebiwabaan..$^{5}$ Dalam ayat ini juga disebutkan tentang tata cara berkomunikasi dengan kedua orang tua yaitu dengan mengedepankan tata cara, sikap dan perilaku yang baik.

2. Standar Proses.

Standar proses sesuai PP Nomor 19 Tahun 2005 pasal 1 adalah standar nasional pendidikan yang berkaitan dengan pelaksanaan pembelajaran pada satu satuan pendidikan untuk mencapai standar kompetensi lulusan. Standar proses berisi kriteria minimal proses pembelajaran pada satuan pendidikan dasar dan menengah di seluruh wilayah hukum Negara Kesatuan Republik Indonesia. Pembelajaran merupakan upaya yang dilakukan untuk membantu seseorang atau kelompok orang sedemikian rupa dengan maksud supaya di samping tercipta proses belajar juga sekaligus supaya proses belajar menjadi lebih efisien dan efektif. proses komunikasi antara guru dan siswa melalui verbal sebagai media utama penyampaian materi pelajaran. Dalam hal belajar dan proses pembelajaran, Islam telah memberi petunjuk, sebagaimana Allah swt., telah berfirman dalam QS. Al-'Imran ayat 164:

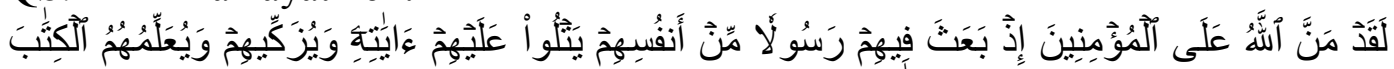

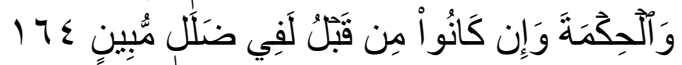

Terjemahnya:

Sungguh Allah telah memberi karunia kepada orang-orang yang beriman ketika Allah mengutus diantara mereka seorang rasul dari golongan mereka sendiri, yang membacakan kepada mereka ayat-ayat Allah, membersihkan (jiwa) mereka, dan mengajarkan kepada mereka Al Kitab dan Al Hikmah.

\footnotetext{
${ }^{4}$ Shalih Bin Muhammad Alu Asy-Syaikh, Tafsir Muyassar, (Jakarta: Darul Haq, 2016), h. 331.

${ }^{5}$ Sidik, Firman. "PEMIKIRAN BISRI MUSTOFA TENTANG NILAI PENDIDIKAN KARAKTER (KAJIAN SURAT AL-HUJURAT AYAT 11-15 TAFSIR AL-IBRIZ)." Tawazun: Jurnal Pendidikan Islam 13.1 (2020): 42-53.
} 
Dan sesungguhnya sebelum (kedatangan Nabi) itu, mereka adalah benarbenar dalam kesesatan yang nyata. ${ }^{6}$

Dalam ayat tersebut ditegaskan bahwa dalam rangka meningkatkan keimanan, memberikan pengetahuan, dan pemahaman kepada manusia, Allah swt., telah mengutus seorang Rasul yang juga sekaligus seorang guru dan pemimpin umat untuk menjalankan tugasnya sebagai Khalifah Fil Ardhi yang mengemban misi pendidikan dan pengajaran. Hasan Langgulung dalam Muh. Arif dan Munirah, mengemukakan bahwa manusia dianggap sebagai khalifah Allah tidak memegang tanggung jawabnya sebagai khalifah kecuali kalua ia dilengkapi dengan potensi yang membolehkannya berbuat demikian, lebih lanjut mengatakan bahwa Al-Qur'an menyatakan adanya beberapa ciri yang dimiliki oleh manusia untuk melaksanakan fungsi kekhalifahannya itu. Ciri yang dimaksud adalah antara lain dari segi fitrahnya yang baik sejak awal. ${ }^{7}$

3. Standar Kompetensi Lulusan

Standar kompetensi lulusan adalah kualifikasi kemampuan lulusan yang mencakup sikap, pengetahuan, dan keterampilan. Standar Kompetensi Lulusan (SKL) adalah kualifikasi kemampuan lulusan yang mencakup sikap, pengetahuan, dan keterampilan (PP Nomor 19Tahun 2005 Bab I Pasal 1 butir 4).

4. Standar Pendidik dan Tenaga Kependidikan.

Standar pendidik dan tenaga kependidikan adalah kriteria pendidikan prajabatan dan kelayakan fisik maupun mental, serta pendidikan dalam jabatan. According to Awang, Jindal Snape \& Barber, Teachers' competency in teaching and learning is an important factor in determining the success of a teaching session. Their ability and wisdom in handling learning activities will have a direct impact on students' active involvement in learning activities. Therefore, the development of teachers competency involving the efforts of fostering positive attitudes. ${ }^{8}$ An-Nasir Muhammad Hamid and Abdul Qadir Dervish Qullah definition Islam education as the directing process of human development on the side of the body, mind, language, behavior, social and religious life geared towards kindness toward perfection. ${ }^{9}$ The definition of teacher is simply the person whose job is teaching. The word "teacher" has broad understanding because every person whose job is teaching can be called a teacher, without any

\footnotetext{
${ }^{6}$ Shalih Bin Muhammad Alu Asy-Syaikh, Tafsir Muyassar, h. 212.

${ }^{7}$ Muh. Arif dan Munirah, Ilmu Pendidikan Islam, (Gorontalo: Sultan Amai Press, 2013), h. 34 .

${ }^{8}$ Jimmi Copriady, "Teachers Competency in the Teaching and Learning of Chemistry Practical”, Mediterranean Journal of Social Sciences, Vol. 5, No. 8, Pekanbaru: University Of Riau, 2014, pp. 312.

${ }^{9}$ Siti Asiah T.,"Transformation of Islamic Education Quality through Regional Autonomy in Bone Bolango Regency, Gorontalo Province", Jurnal Pendidikan Islam, Vol. 6, No. 1, Gorontalo: State Islamic Institute (IAIN) Sultan Amai Gorontalo, 2017, pp. 61.
} 
limitations on the level of education, place or institution and level of students. ${ }^{10}$ Dalam Islam, guru memiliki peran dan posisi yang sangat Penting, yaitu sebagai pemimpin (imam) dan pencerah bagi umat. Sebagaimana Allah swt., berfirman dalam QS. Al-Baqarah ayat 124:

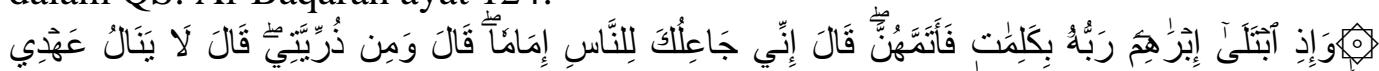

ألنَلِْمِينَ

Terjemahnya:

Dan (ingatlah), ketika Ibrahim diuji Tuhannya dengan beberapa kalimat (perintah dan larangan), lalu Ibrahim menunaikannya. Allah berfirman: "Sesungguhnya Aku akan menjadikanmu imam bagi seluruh manusia". Ibrahim berkata: "(Dan saya mohon juga) dari keturunanku". Allah berfirman: "Janji-Ku (ini) tidak mengenai orang yang zalim. ${ }^{11}$

Ayat tersebut menegaskan bahwa sebagai imam, pemimpin, dan guru harus mampu memberikan keteladanan dan memiliki ilmu pengetahuan serta kompetensi yang tinggi agar dapat menjalankan tugas pendidikan dan pengajaran dengan efektif, efisien, dan produktif. Penulis memberikan pandangan bahwa aktivitas kepemimpinan merupakan upaya secara kolektif dalam berfikir, bertindak dan memecahkan masalah yang dihadapi oleh lembaga secara bersamasama agar tujuan yang telah direncanakan dapat direalisasikan dengan baik.

5. Standar Sarana dan Prasarana

Standar sarana dan prasarana adalah standar nasional pendidikan yang berkaitan dengan kriteria minimal tentang ruang belajar, tempat berolahraga, tempat beribadah, perpustakaan, laboratorium, bengkel kerja, tempat bermain, tempat berkreasi dan berkreasi, serta sumber belajar lain, yang diperlukan untuk menunjang proses pembelajaran, termasuk penggunaan teknologi informasi dan komunikasi. (Peraturan Menteri Pendidikan Nasional Nomor 24 Tahun 2007 Lampiran Bab I, Pasal 1 ayat 8).

6. Standar Pengelolaan

Standar pengelolaan adalah standar nasional pendidikan yang berkaitan dengan perencanaan, pelaksanaan, dan pengawasan. kegiatan pendidikan pada tingkat satuan pendidikan, kabupaten/kota, provinsi, atau nasional agar tercapai efisiensi dan efektivitas penyelenggaraan pendidikan. (PP Nomor 19 Tahun 2005 Pasal 1).

7. Standar Pembiayaan

Standar pembiayaan adalah standar yang mengatur komponen dan besarnya biaya operasi satuan pendidikan yang berlaku selama satu tahun.

\footnotetext{
${ }^{10}$ Ahmad Zainuri, "Level Of Pedagogical Competencies Of State Islamic Elementary School Teachers In Palembang City”, Jurnal Kajian Keislaman, Vol. 22, No. 2, Banjarmasin: Lambung Mangkurat University, 2018, pp. 279.

${ }^{11}$ Shalih Bin Muhammad Alu Asy-Syaikh, Tafsir Muyassar, h. 56.
} 


\section{Standar Penilaian}

Standar penilaian pendidikan adalah standar nasional pendidikan yang berkaitan dengan mekanisme, prosedur, dan instrumen penilaian hasil belajar peserta didik (PP No. 19 Tahun 2005 Bab 1 pasal 1 butir 11).

\section{DAYA SAING}

\section{Konsep Daya Saing Madrasah}

Daya saing merupakan satu bentuk kemampuan yang memungkinkan kita untuk bertahan dalam kehidupan. ${ }^{12}$ According to Srivastava, Competitiveness has become synonymous with economic strength of nation, industry or individual firm. ${ }^{13}$ The term of "competitiveness" is one of the most commonly used concepts in economics but it is not precise enough, what means that there is no generally accepted defi nition of competitiveness. ${ }^{14}$ Ada hal penting yang harus dipahami dalam konsep daya saing yang terkait dengan dua hal, yaitu persepsi orang dan adanya atribut dominan dari organisasi dan produk. Konsep daya saing dalam alQuran dengan dijelaskan melalui penerapan prinsip fastabiul khairaat yakni berlomba-lomba dalam melakukan kebaikan, hal ini sebagaimana diperintahkan oleh Allah swt., dalam surat al-Baqarah ayat 148:

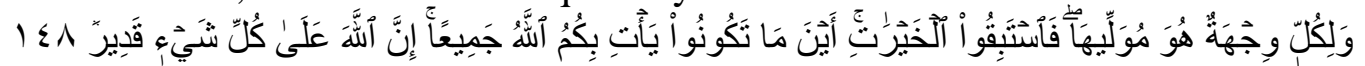
Terjemahnya:

Dan bagi tiap-tiap umat ada kiblatnya (sendiri) yang ia menghadap kepadanya. Maka berlomba-lombalah (dalam membuat) kebaikan. di mana saja kamu berada pasti Allah akan mengumpulkan kamu sekalian (pada hari kiamat). Sesungguhnya Allah Maha Kuasa atas segala sesuatu. (Q.S. alBaqarah ayat148). ${ }^{15}$

Fastabiqul khairaat bukan hanya menjadi kekuatan penggerak (driving force) tapi juga akan menjadi kekuatan magnetik (magnetic force). Artinya perbuatan seperti itu bukan sekadar mampu mengerakkan orang tapi juga dapat menjadi kekuatan yang dapat menyedot perhatian orang banyak. ${ }^{16}$ Daya saing pendidikan tidak dimaksudkan untuk menghancurkan atau mematikan lembaga pendidikan sebagaimana militer menghancurkan lawannya dalam peperangan,

\footnotetext{
${ }^{12}$ Muhammad Saroni, Meningkatkan Daya Sekolah, (Yogyakarta: Ar-Ruzz Media, 2017), h. 23 .

${ }^{13}$ Pragya Bhawsar, Utpal Chattopadhyay, "Competitiveness: Review, Reflections and Directions", National Institute of Industrial Engineering (NITIE), Vol. 16, No. 4, Sirmaur: Indian Institute Of Management, 2015, pp. 666.

${ }^{14}$ Tomasz Siudek, Aldona Zawojska, "Competitiveness In The Economic Concepts, Theories And Empirical Research", Faculty of Economic Sciences, Department of Economics and Organization of Enterprises, Vol. 13, No.1, Poland: Warsaw University of Life Sciences, 2014, pp. 91.

${ }^{15}$ Shalih Bin Muhammad Alu asy-Syaikh, Tafsir Muyassar, h. 67.

${ }^{16}$ Dedy Mulyasana, Pendidikan Bermutu dan Berdaya Saing, (Bandung: Remaja Rosdakarya, 2015), h. 230.
} 
atau tudak seperti para pebisnis menggunakan strategi bersaing untuk melumpuhkan para pesaingnya agar mereka memperoleh keuntungan yang besar.

\section{Dimensi dan Indikator Daya Saing}

Dimensi daya saing suatu perusahaan atau lembaga pendidikan sebagaimana dikemukakan oleh Muhardi dengan mengutip Ward et all adalah terdiri dari biaya (cost), kualitas (quality), waktu penyampaian (delivery), dan fleksibilitas (flexibility). Keempat dimensi tersebut lebih lanjut diterangkan oleh Muhardi lengkap dengan indikatornya sebagai berikut:

a. Biaya adalah dimensi daya saing operasi yang meliputi empat indicator yaitu biaya produksi, produktifitas tenaga kerja, penggunaan kapasitas produksi dan persediaan.

b. Kualitas seperti yang dimaksudkan oleh Muhardi adalah merupakan dimensi daya saing yang juga sangat penting, yaitu meliputi berbagai indikator diantaranya tampilan produk, jangka waktu penerimaan produk, daya tahan produk, kecepatan penyelesaian keluhan konsumen, dan kesesuaian produk terhadap spesifikasi desain.

c. Waktu penyampaian merupakan dimensi daya saing yang meliputi berbagai indikator diantaranya ketepatan waktu produksi, pengurangan waktu tunggu produksi, dan ketepatan waktu penyampaian produk. Ketiga indikator tersebut berkaitan, ketepatan waktu penyampaian produk dapat dipengaruhi oleh ketepatan waktu produksi dan lamanya waktu tunggu produksi. Adapun fleksibilitas merupakan dimensi daya saing operasi yang meliputi berbagai indikator diantaranya macam produk yang dihasilkan, kecepatan menyesuaikan dengan kepentingan lingkungan. ${ }^{17}$

Adapun faktor yang mempengaruhi daya saing adalah sebagai beikut: a) Lokasi, b) Harga, c) Pelayanan, d) Mutu atau kualitas dan Promosi, Sunarto mengemukakan bahwa promosi penjualan terdiri dari insentif jangka pendek untuk mendorong pembelanjaan atau penjualan produk atau jasa, yang mana promosi penjualan ini mencakup suatu variasi yang luas dari alat promosi yang didesain untuk merangsang respons pasar yang lebih cepat, atau yang lebih kuat. ${ }^{18}$

\section{Strategi Peningkatan Daya Saing}

Strategi merupakan tindakan yang bersifat senantiasa meningkat, terusmenerus, dilakukan berdasarkan sudut pandang tentang apa yang diharapkan pelanggan di masa depan. dibawah ini dikemukakan sikap dan langkah strategis sebagai berikut:

a) Strategi bukanlah tujuan melainkan alat untuk mempercepat tercapainya tujuan, karena itu tidak ada yang bersifat mutlak dalam strategi tapi harus

\footnotetext{
${ }^{17}$ Dewi Krisyanti, Pemasaran Jasa Pendidikan (Peningkatan daya saing sekolah), (Jakarta: Pustaka Binaman Pressindo, 2013), h. 42.

${ }^{18}$ David Wijaya, Pemasaran Jasa Pendidikan, (Jakarta: Bumi Aksara Group, 2016), h. 72.
} 
dikembangkan secara fleksibel sesuai dengan iklim, kebutuhan, dan pemasalahan.

b) Melakukan analisis kebutuhan pasar serta memetakan kecenderungan dan kekuatan persaingan.

c) Menetapkan standat mutu dan merumuskan tuntutan kebutuhan pasar dan kecenderungan lingkungan ke dalam garis besar program.

d) Merumuskan program dengan menggunakan prinsip komprehensip, koherensi, keseimbangan, dan keterukuran.

e) Menyusun program strategi alternative yang mampu menjawab berbagai tantangan perubahan. Strategi ini harus disusun secara fleksibel dan mampu menjawab berbagai tantangan dan permasalahan yang kemungkinan akan timbul di masa datang.

f) Memiliki keunggulan khas dan beragam yang tidak dimiliki oleh pesaing, serta memiliki kepekaan terhadap arah perubahan yang terjadi di lingkungan regional, nasional dan global.

g) Menguasai sumber informasi strategis, sehingga sebelum orang lain tahu, ia telah menguasai data, masalah, dan arah persaingan.

h) Apabila telah membidik pangsa pasar pada segmen tertentu (bawah, menengah atau atas), maka promosi, harga, dan system layanan harus sesuai dengan segmen pasar yang dibidik. Kalau membidik segmen bawah, maka promosi tidak menggunakan surat kabar nasional, dan harga pun tidak menggunakan harga menengah.

i) Berorentasi pada keunggulan dan jaminan kepercayaan. Karena itu, pimpinan lembaga tidak sekedar menjual produk, tapi lebih menekankan pada menjual kepercayaan. Juga tidak sekedar menginvestasi modal, tapi secara berangsur menanamkan investasi kepercayaan kepada konsumen. ${ }^{19}$

\section{METODE PENELITIAN}

Metode Penelitian ini dilakukan dengan pendekatan deskriptif kualitatif, dengan menggambarkan kejadian nyata yang ditemui di lapangan. Subyek penelitian ini adalah kepala Madrasah Ibtidaiyah Negeri 1 Kota Gorontalo yang Terakreditasi A. Teknik pengumpulan data dari penelitian ini menggunakan metode observasi, wawancara, dan dokumentasi. Teknik analisa data yang digunakan melalui 4 tahapan, yaitu pengumpulan data, reduksi data, penyajian data, dan penarikan kesimpulan. Penelitian ini memiliki karakteristik yang berbeda dari penelitian sebelumnya yang membahas tentang konsep standar nasional pendidikan. Banyak penelitian yang ditemukan membahas tentang implementasi standar nasional pendidikan di madrasah. sehingga penelitian ini diharapkan menambah khasanah dan wawasan bagi pengambil kebijakan

\footnotetext{
${ }^{19}$ Sedarmayanti, Manajemen Strategi, (Bandung: Refika Aditama, 2014), h. 5.
} 
khususnya Kepala Madrasah dalam mengimplementasikan standar nasional pendidikan di lembaga pendidikan islam. Jenis penelitian ini adalah penelitian deskriptif (pemaparan) hal ini didasarkan pada usaha penelitian untuk mendeskripsikan dan menginterpretasi apa yang sedang berlangsung atau terjadi mengenai kondisi yang sedang berlangsung atau terjadi. Dengan penelitian ini memungkinkan bagi peneliti untuk berusaha memahami arti peristiwa dan kaitannya dalam situasi tertentu serta keadaan suatu objek yang akan diteliti.

Subjek penelitian ini adalah data yang benar diperoleh dari sumber yang dapat dipercaya keabsahannya yaitu berupa data primer serta sekunder. Data primer terdiri dari kepala sekolah, kepala tenaga administrasi dan staf tenaga administrasi. dan data sekunder adalah data yang diperoleh dari sumber tertulis yang ada kaitannya dengan masalah yang di teliti yaitu sejarah berdirinya sekolah, data guru, data tenaga administrasi, siswa, sarana dan prasarana. Analisis data penelitian terlebih dahulu dikumpulkan melalui hasil wawancara, catatan, dan bahan untuk meningkatkan pemahaman terhadap semua hal yang dikumpulkan dan memungkinkan menyajikan apa yang ditemukan. Selanjutnya didukung dengan analisis kualitatis deskriptif dari hasil wawancara untuk mendukung hasil temuan.

\section{HASIL PENELITIAN}

Pendidikan dikatakan bermutu bila memenuhi Peraturan Pemerintah No.19 tahun 2005 tentang Standar Nasional Pendidikan sesuai pasal 3 dan 4. SNP merupakan kriteria minimal tentang sistem pendidikan diseluruh wilayah hukum NKRI (pasal 1 PP No.19 tahun 2007) untuk meningkatkan mutu sumber daya manusia dan pengukuran kualitas pendidikan. Adapun secara lebih jelas, standar yang harus menjadi dasar bagi penyelenggaraan pendidikan sebagaimana tercantum dalam pasal 2 PP No.19 tahun 2007, mencakup 1) standar isi, 2) standar proses, 3) standar kompetensi lulusan, 4) standar pendidik dan tenaga kependidikan, 5) standar sarana dan prasarana, 6) standar pengelolaan, 7) standar pembiayaan, dan 8) standar penilaian pendidikan.

1. Standar Isi

Dalam pelaksanaan kurikulum di MIN 1 Kota Gorontalo secara umum kurikulum madrasah disusun dan dikembangkan oleh madrasah berdasarkan petunjuk dan acuan Badan Standar Nasional Pendidikan (BSNP). Hal senada juga Madrasah Ibtidaiyah Negeri 1 Kota Gorontalo sesuai dengan pengembangan mutu madrasah dan berdasarkan konsep manajemen berbasis madrasah, maka Madrasah Ibtidaiyah Negeri I Kota Gorontalo menyusun dan mengembangkan sendiri kurikulum sesuai dengan kebutuhan satuan pendidikan meskipun harus mengacu pada standar nasional yang ditetapkan BSNP. Artinya pelaksanaan kurikulum yang dilakukan oleh Madrasah Ibtidaiyah Negeri 1 Kota Gorontalo 
yang menjadi objek penelitian menyatakan bahwa mereka menyusun dan mengembangkan kurikulum sesuai kebutuhan madrasah dengan mengacu pada standar nasional pendidikan. Madrasah Ibtidaiyah Negeri 1 Kota Gorontalo dalam pencapaian standar isi melalui pengembangan kurikulum di MIN 1 Kota Gorontalo diungkapkan oleh Ibu Lisna Habibie sebagai berikut: "Kurikulum yang diterapkan mengacu pada kurikulum yang berlaku saat ini yaitu kurikulum 2013, tersedianya perangkat kurikulum yaitu program tahunan, program semester, standar ketuntasan minimal dan silabus mata pelajaran, peningkatan mutu kurikulum dimulai dengan sosialisasi kurikulum 2013, worskshop penilaian kurikulum 2013, bedah permendikbud yang menghasilkan silabus yang dilaksanakan di MIN 1 Kota Gorontalo". ${ }^{20}$

Temuan pada penelitian ini adalah kesesuaian kurikulum nasional dengan kurikulum yang dikembangkan madrasah disajikan secara menarik oleh guru sesuai dengan RPP yang telah dibuat. Pada kurikulum 2013, guru memberikan pembelajaran secara student centered (berpusat pada siswa). Peserta didik lebih aktif belajar, pembelajaran berbasi proyek (Project based learning), dan aktivitas belajar lainnya. Sehingga melatih peserta didik untuk aktif menemukan sendiri pengetahuannya. Hal ini membekali peserta didik untuk dapat bersaing dalam dunia global maupun internasional.

\section{Standar Proses}

Proses pembelajaran dilaksanakan oleh guru yang menyusun RPP disesuaikan dengan skenario yang telah dirancangnya dan dicantumkan sesuai dengan urutan pembelajaran yang sesungguhnya. RPP yang disusun oleh guru dan dilaksanakan dalam proses pembelajaran memberikan kemudahan bagi guru yang bersangkutan untuk mengingat dan menerapkan langkah pembelajaran tersebut. Bagi kepala Madrasah Ibtidaiyah Negeri 1 Kota Gorontalo dapat secara langsung melakukan tindak lanjut terhadap hasil pengawasan proses pembelajaran yang secara berkelanjutan dan berkesinambungan. Upaya tindak lanjut dapat dilakukan dalam bentuk pembinaan intensif, pemberian reward, pemberian teguran atau pemberhentian bila dianggap benar mengecewakan pihak madrasah. Lain halnya terhadap dengan guru yang tidak memungkinkan untuk melakukan tindak lanjut secara maksimal kepada guru yang berstatus PNS karena proses dan prosedurnya sangat panjang dan kewenangan kepala madrasah pun tidak sampai pada tindakan. diungkapkan oleh Ibu Dewi Yanti Muchsin, sebagai berikut: "Perencanaan pembelajaran meliputi 2 hal, yaitu silabus dan Rencana Pelaksanaan Pembelajaran (RPP). Kedua hal tersebut sangat berperan penting guna terselenggaranya pembelajaran yang baik. Dengan perencanaan pembelajaran yang matang, guru dapat lebih mudah dan mempunyai pedoman dalam

${ }^{20}$ Lisna Habibie, Koordinator Standar Isi dan Bidang Kurikulum Madrasah Ibtidaiyah Negeri 1 Kota Gorontalo, Wawancara, Gorontalo: Senin, 13 Juli 2020. 
pelaksanaan pembelajaran. Pembelajaran akan lebih terarah sesuai yang dipersiapkan dalam silabus dan RPP". ${ }^{21}$

Temuan pada penelitian ini sangat menarik terkait dengan pengembangan RPP dan pelaksanaan supervise yang berkelanjutan membantu guru dalam meningkatkan kompetensinya dalam pembelajaran dan bisa menjadi salah satu indikator terhadap minat masyarakat untuk menyekolahkan anaknya adalah dengan cara yang elegan dan memiliki ciri khas yang menjadi unggulannya dan melalui promosi tertentu bagi madrasah negeri dengan mengandalkan popularitas dan dukungan pemerintah. Daya saing yang tinggi akan menempatkan madrasah sebagai institusi pilihan sekaligus memberi kontribusi yang lebih besar dalam memajukan pendidikan nasional" Hal yang demikian merupakan suatu upaya yang dapat dilakukan oleh pihak dalam hal ini Madrasah Ibtidayah Negeri 1 Kota Gorontalo.

3. Standar Kompetensi Lulusan

Siswa di Madrasah Ibtidayah Negeri 1 Kota Gorontalo melalui proses pembelajaran yang kontekstual dan berorientasi pada ilmu pengetahuan dan teknologi akan memperoleh pengalaman belajar untuk menunjukkan kemampuan berpikir logis, kritis, kreatif dan inovatif dalam pengambilan keputusan. Disisi yang lain mereka memiliki ketergantungan dengan kemampuan guru dalam mengajar, bila guru mampu menerapkan kompetensinya secara baik tentu siswa akan memperoleh pengalaman belajar yang baik. Sedangkan pada siswa kelas 1 dan kelas 2, proses pembelajarannya banyak bermain dan menggunakan media yang menarik, baik dilakukan di dalam maupun di luar kelas. Hal demikian ditujukan agar siswa kelas rendah dapat mengalami dan merasakan yang sebenarnya tentang beberapa kondisi konkrit yang harus mereka tahu dan kuasai. Seperti halnya dengan mengenal huruf, mengenal angka, menyusun huruf dan angka serta menulis. Selanjutnya pada kelas rendah bahwa membaca dan menulis merupakan syarat mutlak untuk naik kelas, karena bila belum mampu menulis, membaca dan berhitung akan sangat berdampak pada jenjang kelas selanjutnya. Sebagaimana yang diungkapkan oleh Bapak Marwan Husain Dambu bahwa: "Banyak putra/putri yang sekolah di Madrasah Ibtidaiyah Negeri 1 Kota Gorontalo, Rata-rata mereka memiliki prestasi akademik dan non akademik, misalnya Lutfiyah berprestasi Lomba OSN Matematika juara 1 Tingkat Kota, Mahfudz Juara 1 Hafalan Juz 30 dan Juara 3 Lomba Bercerita Tingkat Provinsi. Selain itu lulusan Madrasah Ibtidaiyah Negeri 1 Kota

\footnotetext{
${ }^{21}$ Dewi Yanti Muchsin, Koodinator Standar Proses, Wawancara, Gorontalo: Senin, 12 Juli 2020.
} 
Gorontalo dapat diterima di MTs/SMP favorit yang mereka kehendaki, bahkan ada yang masuk ke pesantren terkenal di luar Gorontalo". ${ }^{22}$

Temuan Penulis dalam Penelitian ini bahwa Standar kompetensi lulusan yang dilakukan pengelolaannya tidak terdapat perbedaan yang mencolok. Akan tetapi madrasah negeri memiliki basis keagamaan atau kejuruan lebih memiliki adanya penekanan pada ciri khas madrasah tersebut sebagai bentuk pembedanya, hal ini merupakan suatu upaya madrasah negeri dalam memberikan ciri tertentu pada lulusannya sebagai produk unggulan madrasah negeri di tengah masyarakat. 4. Standar Pendidik dan Tenaga Kependidikan

Guru yang mengajar di madrasah ini sudah memiliki kualifikasi akademik minimum sesuai dengan Undang-undang Guru dan Dosen yakni secara umum sudah memiliki Akta Mengajar IV dengan kualifikasi pendidikan Sarjana (S1) dan kualifikasi Magister pendidikan (S2) oleh karena itu guru secara umum sudah berpendidikan S1 dan S2. Sehingga dalam penerapan kompetensi pedagogiknya sesuai dengan prinsip pembelajaran, demikian juga dengan kompetensi keperibadian dan profesionalnya. Jabatan kepala madrasah yang diemban oleh kepala Madrasah berstatus sebagai guru, memiliki sertifikat pendidik, dan memiliki SK sebagai kepala madrasah secara jelas dan sah. Sebagai tenaga pendidik yang telah menerima sertifikat pendidik profesional tentu sudah memiliki kualifikasi pendidikan minimal S-1 dengan memiliki Akta Mengajar IV, serta telah memiliki pengalaman mengajar setidaknya 5 tahun. Hal tersebut tentu akan memberikan pengalaman untuk seorang kepala madrasah dalam kemampuan manajerial yang ditunjukkan dengan keberhasilan mengelola siswa. Temuan Penulis bahwa terdapat perbedaan antara kompetensi Tenaga Pendidik dan Kependidikan dalam pencapaian standar pendidik dan tenaga kependidikan tersebut, sehingga memberikan gambaran bahwa secara umum diharapkan madrasah memiliki tenaga pendidik dan kependidikan yang memiliki standar sesuai dengan BSNP dan mampu menerapkan kompetensinya secara maksimal. Oleh karena itu, pencapaian standar pendidik dan tenaga kependidikan dalam wilayah kerja Kementerian Agama Kota Gorontalo dapat berjalan dengan baik dan teruji.

5. Standar Sarana dan Prasarana

Berkenaan dengan lahan Madrasah Ibtidaiyah Negeri 1 Kota Gorontalo sudah memiliki lahan yang cukup dan mampu menampung jumlah siswa baik saat baris-berbaris, senam, maupun upacara bendera. Artinya madrasah memiliki lahan yang memenuhi ketentuan luas minimal sesuai dengan rasio jumlah siswa. Keadaan di sekitar madrasah berdasarkan hasil observasi peneliti tidak terdapat adanya gejala pencemaran yang berbahaya, artinya lahan madrasah berada di

\footnotetext{
${ }^{22}$ Marwan Husain Dambu, Koordinator Standar Kompetensi Lulusan, Wawancara, Gorontalo: Selasa, 11 Agustus 2020.
} 
lokasi yang terhindar dari gangguan pencemaran air, pencemaran udara, pencemaran tanah, dan kebisingan. Dan yang paling penting terlihat pada madrasah yang menjadi objek penelitian ini menunjukkan adanya upaya kerindangan, seperti banyak tanaman hijau, pagar, dan pohon pelindung yang sudah besar. Fasilitas dalam pengelolaan proses pembelajaran yang dimiliki oleh madrasah negeri diperoleh gambaran bahwa madrasah memiliki fasilitas penunjang pembelajaran yang memadai seperti media, alat peraga, laboratorium, perpustakaan dan alat olah raga. Pendapat lain juga dikemukakan oleh Ibu Fatmawali Kamali bahwa: "Madrasah hendaknya memiliki sarana dan prasarana penunjang pendidikan secara baik dan mencukupi semua kepentingan proses pembelajaran, sehingga kegiatan yang dilakukan akan memberikan hasil yang maksimal serta dapat mencapai tujuan pendidikan di madrasah maupun tujuan secara umum tentang kualitas lulusannya". ${ }^{23}$

Temuan Penilitian ini adalah bahwa pengadaan sarana prasarana di Madrasah Ibtidaiyah Negeri 1 Kota Gorontalo merupakan otonomi madrasah dengan menggunakan bantuan anggaran madrasah dari pemerintah, bantuan dari BOS. Pengadaan sarana prasarana berdasarkan keputusan kepala madrasah berkoordinasi dengan bendahara. Proses pengadaan sarana prasarana tersebut dilakukan dengan pembelian kemudian di distribusikan di masing kelas dan ruang kerja.

6. Standar Pengelolaan

Standar pengelolaan pada Madrasah Ibtidaiyah Negeri 1 Kota Gorontalo dalam wilayah kerja Kementerian Agama Kota Gorontalo telah memiliki Standar nasional pendidikan dan dapat memberikan pengalaman khusus bagi peneliti dalam mengamati dan meneliti semua yang telah dilakukan oleh manajemen Mutu Terpadu. Pengelolaan yang dilakukan menunjukkan telah berjalan dengan baik dan maksimal, meskipun masih ada beberapa hal yang harus mendapat dukungan penuh dari pemerintah dan tidak bersifat mengintervensi penyelenggara madrasah. Kenyataan yang menunjukkan bahwa madrasah Negeri memiliki keunggulan dalam memiliki sarana dan prasarana adalah hal yang tidak berlaku secara umum, sebab bagi madrasah negeri memiliki kemapanan finansial. Temuan Penelitian ini bahwa madrasah ini lebih mengutamakan kompetensi penyelenggara madrasah yang lebih berpotensi dalam rekrutment ketenagaan, sehingga madrasah ini memiliki tenaga yang lebih handal dan berkompetensi, walaupun hal ini tidak berlaku pada semua madrasah. Artinya keadaan ini hanya bagi madrasah negeri yang sudah memiliki kemampuan financial yang cukup mapan dan memiliki tujuan untuk kemajuan yang tinggi.

\footnotetext{
${ }^{23}$ Fatmawati Kamali, Koordinator Standar Sarana dan Prasarana, Wawancara, Gorontalo: Jumat, 11 September 2020.
} 


\section{Pencapaian Standar Pembiayaan}

Untuk memberikan gambaran yang jelas dalam penganggaran di Madrasah Ibtidaiyah Negeri 1 Kota Gorontalo, maka madrasah memiliki rencana kerja dan anggaran madrasah, ungkap Yayu Rahayu Ngiu selaku bendahara madrasah, mengungkapkan bahwa: "setiap awal tahun anggaran menyusun Rencana Kerja dan Anggaran Madrasah hal ini berkenaan dengan kegiatan dan anggaran yang terutama dari dana BOS. Rencana kerja dan anggaran madrasah yang didokumentasikan memuat semua anggaran yang bersumber dari seluruh sumber keuangan madrasah, seperti dari BOS, komite madrasah, investasi lain yang ikut berpartisipasi dalam pengembangan sekolah, hal ini sesuai Dengan dokumentasi yang diarsipkan oleh bendahara dan perangkat staf madrasah. ${ }^{24}$ Hal ini sebagaimana dikemukakan oleh Ibu Farhan Hiyoda bahwa: "Keuangan madrasah akan sangat tergantung dengan keterbukaan dan ketepatan penggunaan anggaran dalam melakukan pembelanjaan, apabila Bagus pengelolaannya Maka akan Terkesan bagus juga penyelenggaraan pendidikan di madrasah tersebut." Pendapat ini menjelaskan betapa pentingnya pengelolaan madrasah dalam hal pembiayaan madrasah untuk dilakukan secara terbuka dan berkeadilan, yang mampu membiayai semua aspek penyelenggaraan pendidikan secara merata dan memberikan prioritas pada kegiatan yang menyentuh kegiatan kesiswaan. Pencapaian yang dilakukan secara umum sudah baik dan tidak terdapat penyalahgunaan anggaran, di madrasah negeri khususnya Madrasah Ibtidaiyah Negeri 1 Kota Gorontalo walaupun secara prioritas hanya bersumber dari dana BOS. Dalam upaya peningkatan mutu pendidikan, maka paling tidak ada 3 faktor yang harus diperhatikan, yaitu; input, proses dan output. Ketiga faktor ini merupakan kesatuan yang tak dapat dipisahkan atau dalam arti sederhana merupakan komponen yang saling menunjang. Dalam konteks pengelolaan anggaran, maka input berkaitan erat dengan sumber dana/anggaran madrasah dalam menunjang proses pembelajaran". 25

Temuan Pada Penelitian ini adalah bahwa pengelolaan anggaran di Madrasah ini sangat transparan, sehingga tidak adalagi terjadi penyelewengan dana. Hal ini juga jelas karena disetiap bulan di buatkan laporan pertanggung jawaban, kemudian dievaluasikan pada akhir tahun. Dan memang diakui bahwa dalam hal peningkatan mutu pendidikan maka pihak sekolah harus benar-benar memperhatikan input, proses dan output. Ketiga hal ini tidak berdiri sendiri akan tetapi saling berkaitan satu sama lain. jika dikaitkan dengan masalah pengelolaan anggaran dalam upaya peningkatan mutu pendidikan maka ketiga faktor ini

\footnotetext{
${ }^{24}$ Srirahayu Ngiu, Bendahara Madrasah Ibtidaiyah Negeri 1 Kota Gorontalo, Wawancara, Gorontalo: Jumat, 11 September 2020.

${ }^{25}$ Farhan Hiyoda, Koordinator Standar Pembiayaan, Wawancara, Gorontalo: Jumat, 11 September 2020.
} 
mutlak dilakukan agar sekolah atau madrasah tetap eksis dan dapat menjawab tuntutan masyarakat akan lembaga pendidikan yang bermutu."

8. Pencapaian Standar Penilaian

Persiapan dalam pelaksanaan penilaian, diantaranya membuat kepanitiaan kerja, menyiapkan kisi soal, menyiapkan soal dan melaksanakan tes, dilanjutkan dengan kegiatan koreksi dan analisis. Rancangan kisi dan soal didokumentasikan secara jelas dan rapi oleh tim kerja. Hal ini dimaksudkan untuk mempermudah bagi guru dan siswa dalam melaksanakan kegiatan evaluasi pembelajaran, baik harian, mingguan, bulanan maupun semester. Hasil pelaksanaan evaluasi tersebut dilakukan analisis dan tindak lanjut sesuai dengan hasil yang diperoleh, bisa berupa pengayaan bagi siswa yang sudah dianggap mampu, dan bisa perbaikan atau remedial bagi siswa yang dianggap masih kurang dalam mencapai hasil belajar dengan ketetapan KKM. Pelaksanaan penilaian yang dilakukan oleh guru, dimulai dari penilaian kelas pada saat pembelajaran berlangsung sampai dengan penilaian akhir semester dan penilaian kenaikan kelas. Artinya pada kenyataan yang dijelaskan, bahwa madrasah negeri dan swasta terdapat persamaan yang diatur dan dipandu dalam BSNP tentang standar penilaian hasil pembelajaran di madrasah.

\section{KESIMPULAN}

Berdasarkan hasil penelitian dan pembahasan dapat diangkat beberapa simpulan sebagai berikut: Implementasi Standar Nasional Pendidikan di Madrasah Ibtidaiyah Negeri 1 Kota Gorontalo dapat diwujudkan dengan baik, merujuk pada delapan Standar Pendidikan Nasional tersebut yaitu: a) Standar Isi, b) Standar Proses, c). Standar Kompetensi Lulusan, d) Standar Tenaga Pendidik dan Tenaga Kependidikan, e) Standar Sarana dan Prasarana, f) Standar Pengelolaan, g) Standar Pembiayaan, dan h) Standar Penilaian. Implementasi Nasional pendidikan yang dimaksud didasarkan pada pemenuhan standar yang ditetapkan didalam Standar Nasional Pendidikan sehingga mampu meningkatkan daya saing madrasah juga berimplikasi pada peningkatan kualitas dan minat masyarakat yang tinggi untuk menyekolahkan anaknya di Madrasah Ibtidaiyah Negeri 1 Kota Gorontalo.

\section{DAFTAR PUSTAKA}

Asiah, Siti T. Transformation of Islamic Education Quality through Regional Autonomy in Bone Bolango Regency, Gorontalo Province. Jurnal Pendidikan Islam, Vol. 6, No. 1, Gorontalo: State Islamic Institute (IAIN) Sultan Amai Gorontalo, 2017.

Asy-Syaikh Alu, Muhammad Bin Shalih. Tafsir Muyassar. Jakarta: Darul Haq, 2016. 
Chattopadhyay, Utpal dan Bhawsar, Pragya. Competitiveness: Review, Reflections and Directions. National Institute of Industrial Engineering (NITIE), Vol. 16, No. 4, Sirmaur: Indian Institute Of Management, 2015.

Copriady, Jimmi. Teachers Competency in the Teaching and Learning of Chemistry Practical. Mediterranean Journal of Social Sciences, Vol. 5, No. 8, Pekanbaru: University Of Riau, 2014.

Ellywati, Jaya Fuadi Syahril Alfi. Implementasi Standar Nasional Pendidikan di Kabupaten Aceh Besar Suatu Persepsi dan Harapan Masyarakat. Pendidikan Ekonomi FKIP Universitas Syiah Kuala, Vol. 3, No.1, Banda Aceh: Universitas Abulyatama, 2019.

Krisyanti, Dewi. Pemasaran Jasa Pendidikan (Peningkatan daya saing sekolah. Jakarta: Pustaka Binaman Pressindo, 2013.

Mulyasana, Dedy. Pendidikan Bermutu dan Berdaya Saing, (Bandung: Remaja Rosdakarya, 2015.

Munirah, dan Muh. Arif. Ilmu Pendidikan Islam. Gorontalo: Sultan Amai Press, 2013.

Peraturan Menteri Pendidikan Nasional Republik Indonesia No. 19 tahun 2005 tentang Standar Nasional Pendidikan. Jakarta: Direktorat Pembinaan Sekolah Menengah Atas, 2019.

Rahmat, Abdul. Pengantar Pendidikan (Teori, Konsep dan Aplikasi). Gorontalo: Ideas Publishing, 2014.

Saroni, Muhammad. Meningkatkan Daya Sekolah. Yogyakarta: Ar-Ruzz Media, 2017.

Sidik, Firman. "PEMIKIRAN BISRI MUSTOFA TENTANG NILAI TAFSIR AL-IBRIZ)." Tawazun: Jurnal Pendidikan Islam 13.1 (2020): 42-53.

Siudek, Tomasz dan Zawojska, Aldona. Competitiveness In The Economic Concepts, Theories And Empirical Research. Faculty of Economic Sciences, Department of Economics and Organization of Enterprises, Vol. 13, No.1, Poland: Warsaw University of Life Sciences, 2014.

Wijaya, David. Pemasaran Jasa Pendidikan. Jakarta: Bumi Aksara Group, 2016.

Zainuri, Ahmad. Level Of Pedagogical Competencies Of State Islamic Elementary School Teachers In Palembang City. Jurnal Kajian Keislaman, Vol. 22, No. 2, Banjarmasin: Lambung Mangkurat University, 2018. 